\title{
Solvent Induced Luminescence in Supramolecular Heterobimetallic Gold(I)- Copper(I) Complexes with a Bidentate Nitrile Ligand
}

\author{
Eduardo J. Fernández,,a, Antonio Laguna*,b, José M. López-de-Luzuriaga ${ }^{\mathrm{a}}$, Miguel Monge ${ }^{\mathrm{a}}$, Manuel \\ Montiel $^{\mathrm{a}}$, M. Elena Olmos ${ }^{\mathrm{a}}$ and María Rodríguez-Castillo ${ }^{\mathrm{a}}$
}

\author{
${ }^{a}$ Departamento de Química, Universidad de La Rioja, Grupo de Síntesis Química de La Rioja, UA-CSIC. Complejo \\ Científico-Tecnológico, 26004-Logroño, Spain \\ ${ }^{b}$ Departamento de Química Inorgánica, Instituto de Ciencia de Materiales de Aragón, Universidad de Zaragoza-CSIC, \\ 0009-Zaragoza, Spain
}

\begin{abstract}
Heterobimetallic complexes $\left[\mathrm{Cu}(\mathrm{N} \equiv \mathrm{C}-\mathrm{Cy}-\mathrm{C} \equiv \mathrm{N})_{2}\right]\left[\mathrm{Au}\left(\mathrm{C}_{6} \mathrm{~F}_{5}\right)_{2}\right] \cdot 0.5 \quad$ Toluene $\quad(\mathbf{1}) \quad$ and $\quad[\mathrm{Cu}(\mathrm{N} \equiv \mathrm{C}-\mathrm{Cy}-$ $\left.\mathrm{C} \equiv \mathrm{N})_{2}\right]\left[\mathrm{Au}\left(\mathrm{C}_{6} \mathrm{~F}_{5}\right)_{2}\right] \cdot \mathrm{CH}_{2} \mathrm{Cl}_{2}(2)$ and $\left[\mathrm{AuCu}\left(\mathrm{C}_{6} \mathrm{~F}_{5}\right)_{2}(\mathrm{~N} \equiv \mathrm{C}-\mathrm{Cy}-\mathrm{C} \equiv \mathrm{N})_{2}\right] \cdot \mathrm{CH}_{2} \mathrm{Cl}_{2}(\mathbf{3})$ (with the same stoichiometry but different structure) have been synthesized and the crystal structure of complex $2 \cdot \mathrm{CH}_{2} \mathrm{Cl}_{2}$ has been characterized through X-ray diffraction studies. The structure shows a cationic $\left[\mathrm{Cu}(\mathrm{N} \equiv \mathrm{C}-\mathrm{Cy}-\mathrm{C} \equiv \mathrm{N})_{2}\right]^{+}$polymer that runs parallel to the crystallographic $y$ axis, which is formed by the copper centers and the nitrile bridging ligands, and $\left[\mathrm{Au}\left(\mathrm{C}_{6} \mathrm{~F}_{5}\right)_{2}\right]^{-}$anions that link the polym-

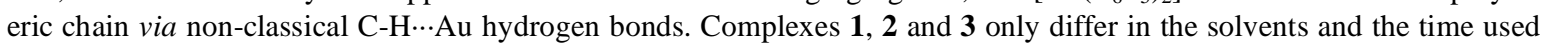
for their synthesis but this greatly affects their photophysical properties. Complexes 1, 2 and $\mathbf{3}$ are brightly luminescent in solid state at room temperature with lifetimes in the microseconds range. Complexes $\mathbf{1}$ and $\mathbf{2}$ display emissions arising from IL transitions while for complex $\mathbf{3}$ an emission arising from a MLCT is proposed.
\end{abstract}

Heterometallic $\mathrm{Au}(\mathrm{I})-\mathrm{M}(\mathrm{I})$ complexes $(\mathrm{M}=\mathrm{Ag}(\mathrm{I}), \mathrm{Tl}(\mathrm{I})$ and $\mathrm{Cu}(\mathrm{I}))$ built up through the acid-base reaction between $\left[\mathrm{Au}\left(\mathrm{C}_{6} \mathrm{X}_{5}\right)_{2}\right]^{-}$and $\mathrm{M}^{+}$salts are an important class of compounds from experimental, theoretical $[1,2]$ and photophysical [3] viewpoints. In most cases this interest arises from the presence of metallophilic interactions which are usually responsible for the arrangements found in the solid state such as dimers, polymeric linear chains, 2D-sheets or 3Dnetworks. What is found in these cases is that the presence of $\mathrm{Au}(\mathrm{I}) \cdots \mathrm{M}$ closed-shell interactions governs the structural dispositions found in the solid state. Also, many of these complexes display fascinating luminescent properties that are closely related to the presence of metallophilic interactions. Taking into account the heterometals, the ligands, the intermetallic distances and the number of metal-metal interactions it is possible to obtain complexes in which the luminescent properties vary from blue to red emissions and from fluorescent to phosphorescent emitters.

This trends have been recently revised [3] and just as an example, while heterometallic $\mathrm{Au}-\mathrm{Ag}$ and $\mathrm{Au}-\mathrm{Cu}$ polymeric complexes built up from $\left[\mathrm{Au}_{2} \mathrm{M}_{2}\left(\mathrm{C}_{6} \mathrm{~F}_{5}\right)_{4}\left(\mathrm{NCCH}_{3}\right)\right](\mathrm{M}=\mathrm{Ag}$ or $\mathrm{Cu})$ [4] tetranuclear units display fluorescent yellow-green or yellow emissions, discrete molecules as $\left\{\left[\mathrm{Tl}\left(\eta^{6}-\right.\right.\right.$ toluene)][Au( $\left.\left.\left(\mathrm{C}_{6} \mathrm{Cl}_{5}\right)_{2}\right]\right\}$ [5] is a blue emitter with a lifetime in the microseconds range. In both examples the synthetic strategy is common but the heterometals, the ligands and the intermetallic interactions differ and are responsible for a different photoluminescent behaviour. In another example, a

*Address correspondence to these authors at the Departamento de Química, Universidad de La Rioja, UA-CSIC. Complejo Científico-Tecnológico, 26004-Logroño, Spain; Tel: +34 941299 642; Fax +34 941299 621;

E-mail: eduardo.fernandez@unirioja.es fluorescent red emission is obtained from $\left\{\left[\mathrm{AuTl}\left(\mathrm{C}_{6} \mathrm{Cl}_{5}\right)_{2}\right.\right.$ (bipy) $]_{\mathrm{n}} \cdot 0.5$ toluene $\}_{\mathrm{n}}$ (bipy $=4,4$ '-bipyridine) complex [6].

As regards $\mathrm{Au}(\mathrm{I})-\mathrm{Cu}(\mathrm{I})$ complexes built up through this acid-base strategy, we have recently reported the synthesis and structural characterization of complexes $\left[\mathrm{AuCu}\left(\mathrm{C}_{6} \mathrm{~F}_{5}\right)_{2}\right.$ $\left.\left(\mathrm{N} \equiv \mathrm{CCH}_{3}\right)\left(\mathrm{C}_{4} \mathrm{H}_{4} \mathrm{~N}_{2}\right)\right]_{\mathrm{n}}$ [7] and $\left[\mathrm{Au}_{2} \mathrm{Cu}_{2}\left(\mathrm{C}_{6} \mathrm{~F}_{5}\right)_{4}\left(\mathrm{~N} \equiv \mathrm{CCH}_{3}\right)_{2}\right]_{\mathrm{n}}$ [4] in which the copper(I) centers display a distorted tetrahedral environment. In the first case, the tetrahedral environment is completed by the coordination of two pyrimidine ligands, one acetonitrile ligand and a strong $\mathrm{Au}(\mathrm{I}) \cdots \mathrm{Cu}(\mathrm{I})$ metallophilic interaction. In the second example the copper center completes its coordination sphere by the coordination to only one acetonitrile molecule, two $\mathrm{Au}(\mathrm{I}) \cdots \mathrm{Cu}(\mathrm{I})$ contacts and one $\mathrm{Cu}(\mathrm{I}) \cdots \mathrm{C}$ contact. What it seems likely is that when the copper centers are ligand-unsaturated the basic aurate fragment is able to stabilize the copper atom through metallophilic interactions.(see Scheme 1) These structural situations in which metallophilic interactions take place lead to compounds that display very interesting photoluminescent properties. Another interesting structural feature is the key role that solvent molecules would play in the formation of different structural arrangements found in the solid state and their influence in the photophysical properties [8].

At this point we wondered whether the presence of larger amounts of a nitrile ligand would compete or not with the metallophilic interactions leading to well-separated ionic counterparts $\left[\mathrm{Au}\left(\mathrm{C}_{6} \mathrm{~F}_{5}\right)_{2}\right]^{-}$and $\left[\mathrm{CuL}_{2}\right]^{+}(\mathrm{L}=$ bidentate nitrile ligand) (see Scheme 1c). This strategy would give rise to a new family of complexes in which the acid-base stacking would be prevented by complete saturation of the $\mathrm{Cu}(\mathrm{I})$ centers with nitrile ligands and the photoluminescent properties, if present, would have a different origin. 


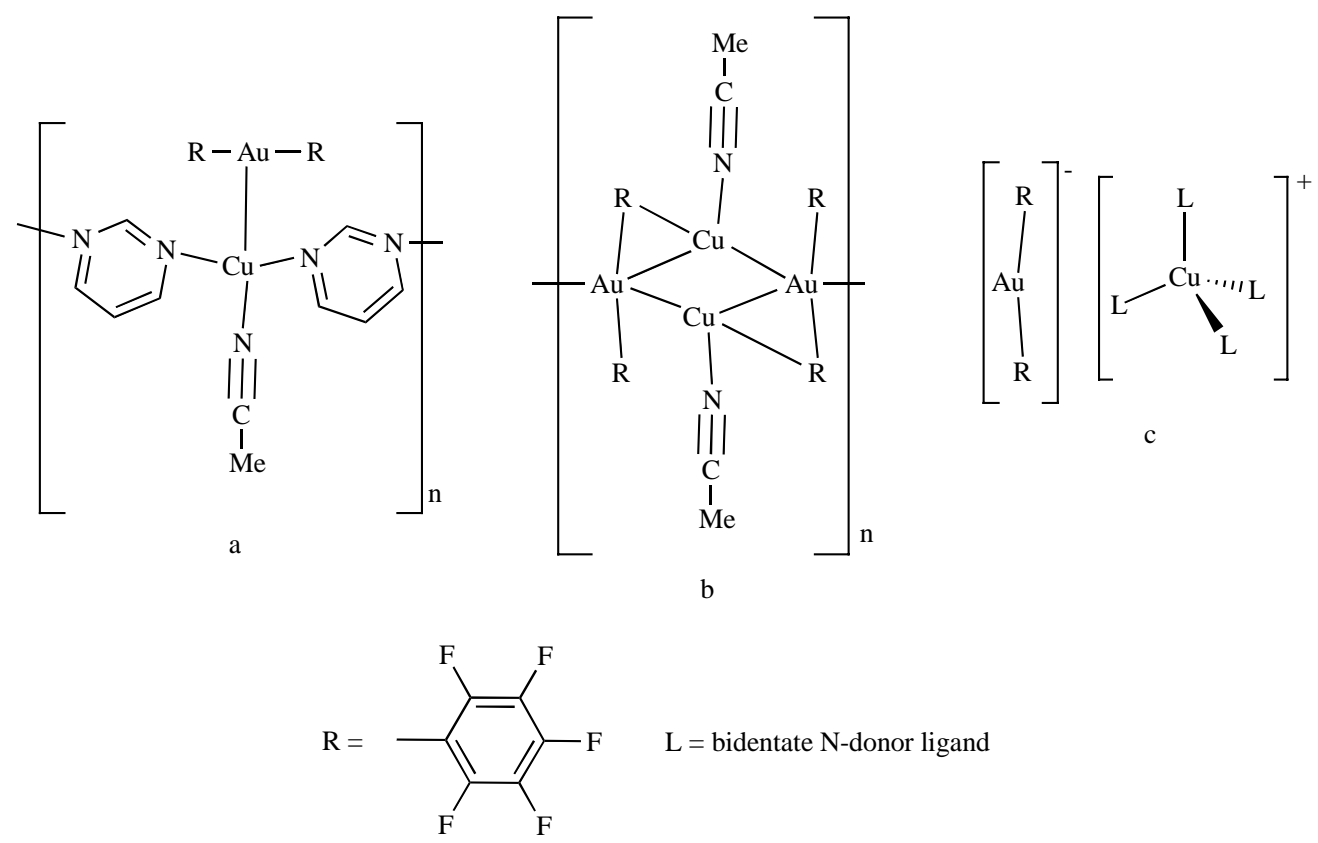

Scheme 1. Different $\mathrm{Cu}(\mathrm{I})$ environments found in $\mathrm{Au}(\mathrm{I})-\mathrm{Cu}(\mathrm{I})$ compounds built up from $\left[\mathrm{Au}\left(\mathrm{C}_{6} \mathrm{~F}_{5}\right)_{2}\right]^{-}, \mathrm{Cu}^{+}$and nitrile ligands $(\mathbf{a}$ and $\mathbf{b})$ and proposed model compound (c) for $\mathrm{Au}-\mathrm{Cu}$ complexes with saturated $\mathrm{Cu}(\mathrm{I})$ centers.

Hence, herein we report the synthesis and photophysical properties of a new type of $\mathrm{Au}-\mathrm{Cu}$ complexes $[\mathrm{Cu}(\mathrm{N} \equiv \mathrm{C}-\mathrm{Cy}-$ $\left.\mathrm{C} \equiv \mathrm{N})_{2}\right]\left[\mathrm{Au}\left(\mathrm{C}_{6} \mathrm{~F}_{5}\right)_{2}\right] \cdot 0.5 \quad$ Toluene $\quad(\mathbf{1}), \quad[\mathrm{Cu}(\mathrm{N} \equiv \mathrm{C}-\mathrm{Cy}-$ $\left.\mathrm{C} \equiv \mathrm{N})_{2}\right]\left[\mathrm{Au}\left(\mathrm{C}_{6} \mathrm{~F}_{5}\right)_{2}\right] \cdot \mathrm{CH}_{2} \mathrm{Cl}_{2}(2)$ and $\left[\mathrm{AuCu}\left(\mathrm{C}_{6} \mathrm{~F}_{5}\right)_{2}(\mathrm{~N} \equiv \mathrm{C}-\mathrm{Cy}-\right.$ $\left.\mathrm{C} \equiv \mathrm{N})_{2}\right] \cdot \mathrm{CH}_{2} \mathrm{Cl}_{2}$ (3) using the bidentate $\mathrm{N}$-donor ligand 1,4cyclohexanedicarbonitrile bonded to $\mathrm{Cu}(\mathrm{I})$ in different solvents as toluene and dichloromethane. The use of different solvents for the crystallization of the complexes $\mathbf{1 , 2}$ and $\mathbf{3}$ leads to new structural arrangements in the solid state. We also study the relationship between the luminescent properties and the possible structural changes upon addition of dichloromethane to complex $\mathbf{1}$ in a fast reaction or in a slow diffusion process of $n$-hexane into dichloromethane.

\section{RESULTS AND DISCUSSION}

The ligand 1,4-cyclohexanedicarbonitrile reacts with the gold-copper starting material $\left[\mathrm{AuCu}\left(\mathrm{C}_{6} \mathrm{~F}_{5}\right)_{2}(\mathrm{~N} \equiv \mathrm{C}-\mathrm{Me})_{2}\right]$ in a 2:1 molar ratio in toluene as solvent, leading to a compound of stoichiometry $\left[\mathrm{Cu}(\mathrm{N} \equiv \mathrm{C}-\mathrm{Cy}-\mathrm{C} \equiv \mathrm{N})_{2}\right]\left[\mathrm{Au}\left(\mathrm{C}_{6} \mathrm{~F}_{5}\right)_{2}\right] \cdot 0.5$ Toluene (1), by displacement of the acetonitrile ligand. Addition of $\mathrm{CH}_{2} \mathrm{Cl}_{2}$ to complex 1 and slow diffusion of n-hexane leads to complex $\left[\mathrm{Cu}(\mathrm{N} \equiv \mathrm{C}-\mathrm{Cy}-\mathrm{C} \equiv \mathrm{N})_{2}\right]\left[\mathrm{Au}\left(\mathrm{C}_{6} \mathrm{~F}_{5}\right)_{2}\right] \cdot \mathrm{CH}_{2} \mathrm{Cl}_{2}$ (2). By contrast, addition of $\mathrm{CH}_{2} \mathrm{Cl}_{2}$ to complex 1 and further evaporation of the solvent under vacuum leads to complex $\left[\mathrm{AuCu}\left(\mathrm{C}_{6} \mathrm{~F}_{5}\right)_{2}(\mathrm{~N} \equiv \mathrm{C}-\mathrm{Cy}-\mathrm{C} \equiv \mathrm{N})_{2}\right] \cdot \mathrm{CH}_{2} \mathrm{Cl}_{2}(\mathbf{3})$.

All physical and spectroscopic properties are in accordance with the proposed stoichiometries. It is worth mentioning that complexes 2 and $\mathbf{3}$ display the same stoichiometry but a different arrangement in their structures. Taking into account their photophysical properties (see below) a $\mathrm{Au}(\mathrm{I}) \cdots \mathrm{Cu}(\mathrm{I})$ intermetallic interaction is proposed for complex 3. Complex $\mathbf{1}$ is soluble in $\mathrm{CH}_{2} \mathrm{Cl}_{2}$ and partially soluble in toluene while complexes $\mathbf{2}$ and $\mathbf{3}$ are soluble in $\mathrm{CH}_{2} \mathrm{Cl}_{2}$ and insoluble in toluene. It is worth mentioning that upon addition of $\mathrm{CH}_{2} \mathrm{Cl}_{2}$ to complex 1 it converts into complex 3 but addition of toluene to complex $\mathbf{3}$ does not recover com- plex 1. Complex 3 is also soluble and decomposes in $\mathrm{CH}_{3} \mathrm{CN}$ and $\mathrm{MeOH}$.

Complexes 1, 2 and 3 show similar ${ }^{19} \mathrm{~F}$ NMR profiles, displaying the signals corresponding to the $\mathrm{C}_{6} \mathrm{~F}_{5}$ groups bonded to $\mathrm{Au}(\mathrm{I})$ in the free $\left[\mathrm{Au}\left(\mathrm{C}_{6} \mathrm{~F}_{5}\right)_{2}\right]^{-}$units at approximately $-114.9\left(\mathrm{~F}_{o}\right),-161.7\left(\mathrm{~F}_{p}\right),-162.9\left(\mathrm{~F}_{m}\right)$ ppm. The ${ }^{1} \mathrm{H}$ NMR spectra for complexes $\mathbf{1}, \mathbf{2}$ and $\mathbf{3}$ show the signals corresponding to the cis/trans mixture (ca 70:30) of the ligand 1,4-cyclohexanedicarbonitrile that, in solution, seems to be detached from the copper(I) centers since the chemical shifts are similar to the ones of the free ligand. In the case of complex 2 the crystal structure displays a cis conformation for the 1,4-cyclohexanedicarbonitrile ligand.

Single crystals of the pentafluorophenyl complex 2. $\mathrm{CH}_{2} \mathrm{Cl}_{2}$ suitable for $\mathrm{x}$-ray diffraction studies were obtained by slow diffusion of $n$-hexane into a solution of the complex in dichloromethane. Its crystal structure consists of a cationic polymer that runs parallel to the crystallographic $y$ axis, which is formed by the coppercenters and the nitrile bridging ligands, and $\left[\mathrm{Au}\left(\mathrm{C}_{6} \mathrm{~F}_{5}\right)_{2}\right]^{-}$anions that link the polymeric chain via non-classical $\mathrm{C}-\mathrm{H} \cdots \mathrm{Au}$ hydrogen bonds (Fig. 1). The gold(I) atoms are linearly coordinated to two pentafluorophenyl rings with typical Au-C bond distances (2.046(5) and 2.051(5) $\AA$ ), while the copper(I) centers display a tetrahedral environment by coordination to four nitrogen atoms of different nitrile molecules, which act as bridges between two copper centers (see Fig. 2). The $\mathrm{Cu}-\mathrm{N}$ bond lengths of 1.982(4), 1.996(4), 1.998(5) and 2.025(5) $\AA$ are longer than in the related acetonitrile complex $\left[\mathrm{Au}_{2} \mathrm{Cu}_{2}\left(\mathrm{C}_{6} \mathrm{~F}_{5}\right)_{4}\left(\mathrm{~N} \equiv \mathrm{CCH}_{3}\right)_{2}\right]_{\mathrm{n}}$ [4] (1.903(4) $\AA$ ), but are in general shorter than the $\mathrm{Cu}-\mathrm{N}$ distance to acetonitrile in $\left[\mathrm{AuCu}\left(\mathrm{C}_{6} \mathrm{~F}_{5}\right)_{2}\left(\mathrm{~N} \equiv \mathrm{CCH}_{3}\right)\left(\mathrm{C}_{4} \mathrm{H}_{4} \mathrm{~N}_{2}\right)\right]_{\mathrm{n}}\left(\mathrm{C}_{4} \mathrm{H}_{4} \mathrm{~N}_{2}=\right.$ Pyrimidine $)$ [7] (2.048(4) $\AA$ ). Interestingly, although $\mathrm{Au} \cdots \mathrm{Cu}$ bonding interactions have been observed in the $\mathrm{Au} / \mathrm{Cu}$ nitrile derivatives $\left[\mathrm{Au}_{2} \mathrm{Cu}_{2}\left(\mathrm{C}_{6} \mathrm{~F}_{5}\right)_{4}\left(\mathrm{~N} \equiv \mathrm{CCH}_{3}\right)_{2}\right]_{\mathrm{n}}$ [4] and $\left[\mathrm{AuCu}\left(\mathrm{C}_{6} \mathrm{~F}_{5}\right)_{2}\right.$ 

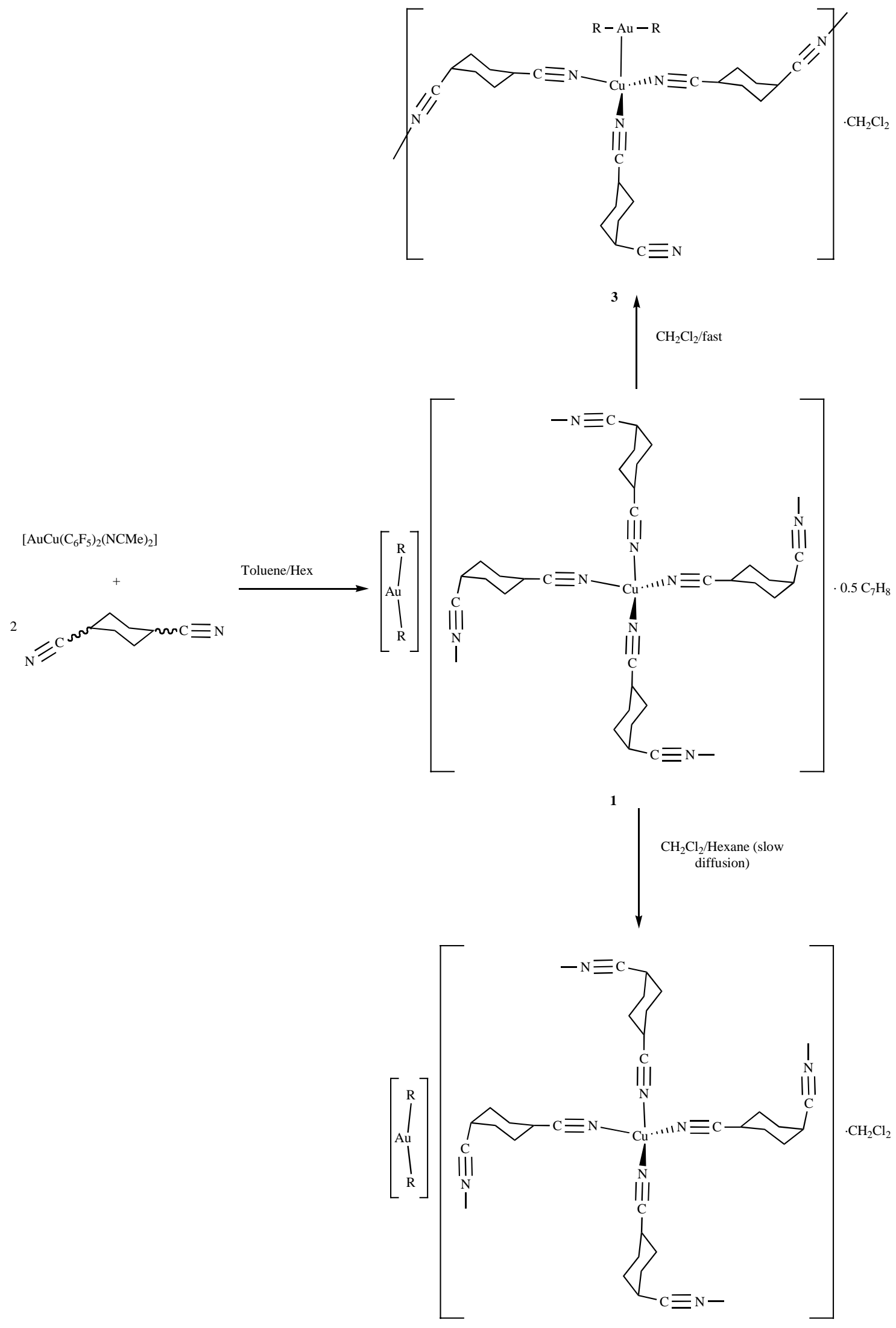

2

Scheme 2. Synthesis of complexes $\left[\mathrm{Cu}(\mathrm{N} \equiv \mathrm{C}-\mathrm{Cy}-\mathrm{C} \equiv \mathrm{N})_{2}\right]\left[\mathrm{Au}\left(\mathrm{C}_{6} \mathrm{~F}_{5}\right)_{2}\right] \cdot 0.5$ Toluene $(\mathbf{1})$ and $\left[\mathrm{Cu}(\mathrm{N} \equiv \mathrm{C}-\mathrm{Cy}-\mathrm{C} \equiv \mathrm{N})_{2}\right]\left[\mathrm{Au}\left(\mathrm{C}_{6} \mathrm{~F}_{5}\right)_{2}\right] \cdot \mathrm{CH}_{2} \mathrm{Cl} \mathrm{Cl}_{2}(\mathbf{2})$ and $\left[\mathrm{AuCu}\left(\mathrm{C}_{6} \mathrm{~F}_{5}\right)_{2}(\mathrm{~N} \equiv \mathrm{C}-\mathrm{Cy}-\mathrm{C} \equiv \mathrm{N})_{2}\right] \cdot \mathrm{CH}_{2} \mathrm{Cl}_{2}(\mathbf{3})$. 


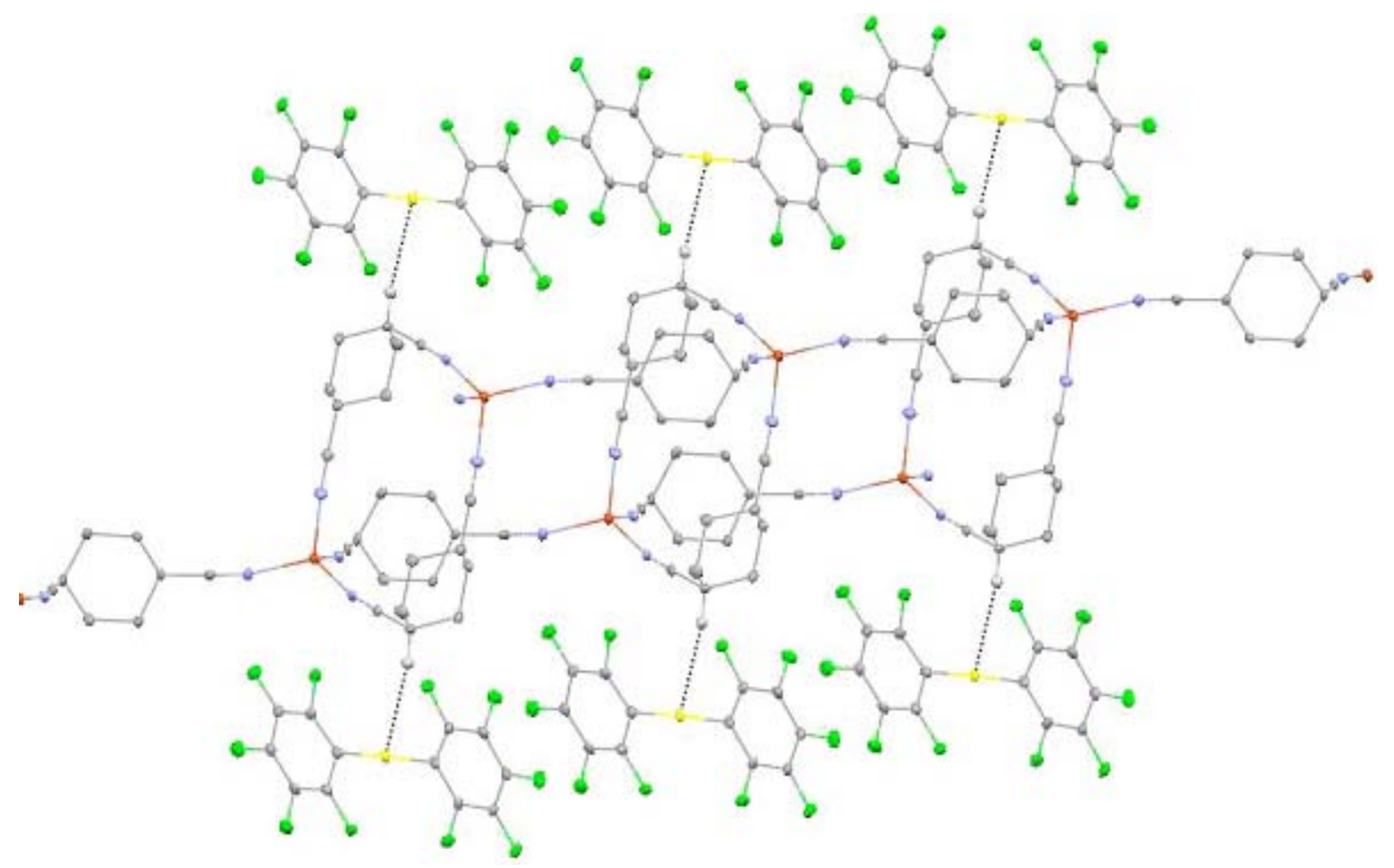

Fig. (1). 3D arrangement for complex $2 \cdot \mathrm{CH}_{2} \mathrm{Cl}_{2}$.

$\left.\left(\mathrm{N} \equiv \mathrm{CCH}_{3}\right)\left(\mathrm{C}_{4} \mathrm{H}_{4} \mathrm{~N}_{2}\right)\right]_{\mathrm{n}}$ [7] previously reported by us, no intermetallic interactions are observed within the crystal structure of $\mathbf{2} \cdot \mathrm{CH}_{2} \mathrm{Cl}_{2}$, since all the metal-metal separations are longer than $6 \AA$. Thus, each $\left[\mathrm{Au}\left(\mathrm{C}_{6} \mathrm{~F}_{5}\right)_{2}\right]^{\text {- fragment binds the }}$ cationic chain only through a non conventional $\mathrm{C}-\mathrm{H} \cdots \mathrm{Au}$ bond between one of the cyclohexane $\mathrm{C}-\mathrm{H}$ bonds and the $\operatorname{gold}(\mathrm{I})$ atom $[\mathrm{Au} \cdots \mathrm{C}=3.798(5) \AA, \mathrm{Au} \cdots \mathrm{H}=2.844(1) \AA, \mathrm{C}-$ $\left.\mathrm{H} \cdots \mathrm{Au}=164.6^{\circ}\right]$, which is of considerable strength taking into account its $\mathrm{Au} \cdots \mathrm{H}$ length and linearity. It is worth noting that the $\mathrm{Au} \cdots \mathrm{H}$ distances in intermolecular $\mathrm{C}-\mathrm{H} \cdots \mathrm{Au}$ hydrogen bonds range from approximately 2.7 to $3.18 \AA$, and the angles vary from 120 to $169^{\circ}$.

The solvate adducts $\mathbf{1}$ and $\mathbf{2}$ and the product of the fast reaction in dichloromethane $\mathbf{3}$ are luminescent in solid state at room temperature but at different energies, which can be related with their different structures.

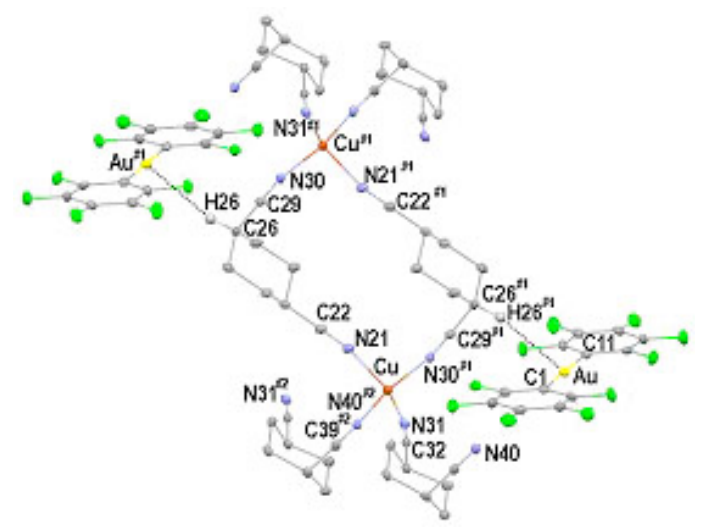

Fig. (2). Crystal structure of complex $2 \cdot \mathrm{CH}_{2} \mathrm{Cl}_{2}$. Hydrogen atoms (except H26) and dichloromethane have been omitted for clarity.
Thus, in complex 2 where the crystal structure shows that there are no interactions between the gold and copper centers, the excitation and emission energies appeared at high energies (exc. at $289 \mathrm{~nm}$, em at $469 \mathrm{~nm}$ ). Similar result is obtained for the X-ray unchacterized complex $\mathbf{1}$. By contrast, complex 3 showed an excitation and emission pair at lower energy 415 and $519 \mathrm{~nm}$, respectively. In addition, by excitation at $290 \mathrm{~nm}$ an emission at $469 \mathrm{~nm}$ was obtained.

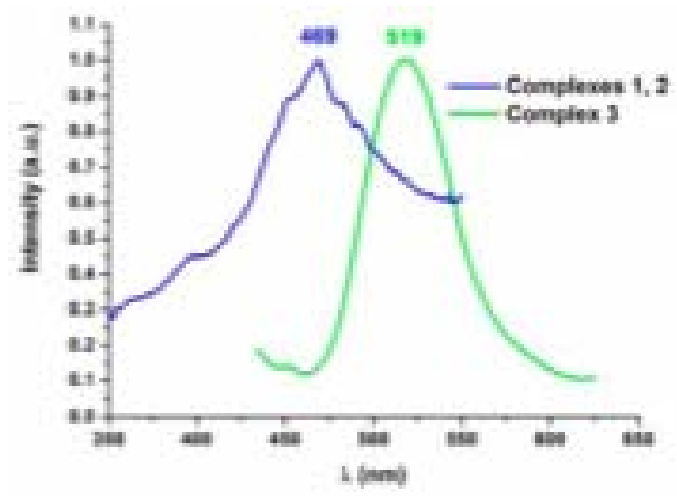

Fig. (3). Emission spectrum for complexes 1 and $\mathbf{2}$ (blue) and low energy emission for complex $\mathbf{3}$ (green).

The lifetime of both emissions were in the microseconds range with values of $7 \mu \mathrm{s}\left(\mathrm{R}^{2}=0.998\right)(\mathrm{em} .519 \mathrm{~nm})$ and 143 $\mu \mathrm{s}\left(\mathrm{R}^{2}=0.995\right)(\mathrm{em} .469 \mathrm{~nm})$, indicating that they arise from excited states of triplet parentage and, consequently, both can be assigned as phosphorescence. The nitrile ligand displayed also a weak emission at $467 \mathrm{~nm}$ with a broad excitation spectra ranging from 290 to $400 \mathrm{~nm}$. The emission was independent of the excitation wavelength in that range. 
The absorption spectra in degassed dichloromethane for the complexes showed similar peaks at $241\left(\varepsilon=6.2 \times 10^{3}\right)$ and $275 \mathrm{~nm}\left(\varepsilon=5.9 \times 10^{3} \mathrm{~mol}^{-1} \mathrm{dm}^{3} \mathrm{~cm}^{-1}\right)$, which also appeared in the precursor gold complex and that we assign to $\pi \pi^{*}$ transitions in the pentafluorophenyl rings.

Taking into account the previous results what is likely is that the emissions in both high and low energy regions have different origins that are dependent on the structures in the complexes. Thus, in complex $\mathbf{2}$ with a polymeric structure built with copper atoms and nitrile ligands and without metal-metal interactions, only the high energy emission was detected, which appeared at similar wavelength than in the free ligand. This fact precludes a transition located in the pentaflourophenyl rings, a metal to ligand charge transfer or a copper centered emission, which should appear at higher wavelengths [9-12]. The similar behaviour of complex $\mathbf{1}$ is indicative of a similar structure and properties. Therefore what is proposed is an intraligand (IL) transition, probably a $\pi-\pi^{*}$ transition, located in the nitrile groups. In the case of complex $\mathbf{3}$, in addition to the commented transition, an emission at lower energy appeared. The energy of this emission was closed to that observed for the polymeric gold-copper complex $\left[\mathrm{Cu}\left\{\mathrm{Au}\left(\mathrm{C}_{6} \mathrm{~F}_{5}\right)_{2}\right\}\left(\mathrm{CH}_{3} \mathrm{CN}\right)\left(\mu_{2}-\mathrm{C}_{4} \mathrm{H}_{4} \mathrm{~N}_{2}\right)\right]_{\mathrm{n}}$, which emitted at $525 \mathrm{~nm}$ and showed a similar lifetime [7]. In that example gold-copper interactions appeared and the basic gold center contributed to a copper to ligand charge transfer transition (MLCT) that led to the observed emission. In this case we propose a similar origin and, therefore, a polymeric structure in which the gold centers bind to the copper atoms that are also bonded to a number of nitrile ligands is likely.(see Scheme 2) As in the previous example, the dissolution of the complex $\mathbf{3}$ in donor solvents as methanol or acetonitrile and irradiation with UV light provokes the quench of the emission and, in this case, also decomposition of the product is observed, result that is interpreted in terms of the reaction of the formally $\mathrm{d}^{9} \mathrm{Cu}$ (II) in the excited state with the added nucleophiles which destabilizes the ground state and promotes the quenching and, perhaps, breaks the gold copper interaction leading to the decomposition of the product [13-17].

In agreement with the previous structural and photophysical results what it seems is that complex $\mathbf{3}$ is the preferred kinetic structure while complex 2 could be the thermodynamic one since complex $\mathbf{3}$ is obtained by the mixture of reactants in $\mathrm{CH}_{2} \mathrm{Cl}_{2}$ and precipitation occurs very fast while complex $\mathbf{2}$ is obtained by dissolution and longer period of crystallization of complex 1 in dichloromethane. Unfortunately suitable crystals for X-ray studies for complex $\mathbf{3}$ could not be obtained.

\section{ACKNOWLEDGEMENTS}

The D.G.I.(MEC)/FEDER (CTQ2007-67273-C02-02) project is acknowledged for financial support. M. RodríguezCastillo thanks the C.A.R. for a grant.

\section{EXPERIMENTAL PART}

\section{Instrumentation}

Infrared spectra were recorded in the 4000-200 $\mathrm{cm}^{-1}$ range on a Perkin-Elmer FT-IR Spectrum 1000 spectrophotometer, using Nujol mulls between polyethylene sheets. C,
$\mathrm{H}, \mathrm{N}$ analyses were carried out with a C.E. Instrument EA1110 CHNS-O microanalyser. Mass spectra were recorded on a HP-5989B Mass Spectrometer API-Electrospray with interface 59987A. ${ }^{1} \mathrm{H}$ spectra were recorded on a Bruker ARX 400 and ${ }^{19}$ F NMR spectra were on a Bruker ARX 300 in $\mathrm{CD}_{3} \mathrm{CN}$. Chemical shifts are quoted relative to $\mathrm{SiMe}_{4}\left({ }^{1} \mathrm{H}\right.$ external) and $\mathrm{CFCl}_{3}\left({ }^{19} \mathrm{~F}\right.$, external). Absorption spectra in solution were registered on a Hewlett-Packard 8453 diode array UV-visible spectrophotometer. Excitation and emission spectra were recorded with a Jobin-Yvon Horiba Fluorolog 3-22 Tau-3 spectrofluorimeter. Phosphorescence lifetime was recorded with a Fluoromax phosphorimeter accessory containing a UV xenon flash tube with a flash rate between 0.05 and $25 \mathrm{~Hz}$. The lifetime data were fitted using the Jobin-Yvon software package and the Origin 6.1 program.

\section{Preparation of $\left[\mathrm{Cu}(\mathrm{N} \equiv \mathrm{C}-\mathrm{Cy}-\mathrm{C} \equiv \mathrm{N})_{2}\right]\left[\mathrm{Au}\left(\mathrm{C}_{6} \mathrm{~F}_{5}\right)_{2}\right] \cdot 0.5$ Tolu- ene (1)}

To a toluene solution $(20 \mathrm{ml})$ of $\left[\mathrm{AuCu}\left(\mathrm{C}_{6} \mathrm{~F}_{5}\right)_{2}(\mathrm{~N} \equiv \mathrm{C}\right.$ $\mathrm{Me})_{2}$ ] [18] (150 mg, $\left.0.221 \mathrm{mmol}\right)$ was added 1,4cyclohexanedicarbonitrile $(59.3 \mathrm{mg}, 0.442 \mathrm{mmol})$ and after 2 hours of stirring the solvent was evaporated to $c a .5 \mathrm{ml}$. Addition of n-hexane gave rise to complex $\mathbf{1}$ as a white solid. Yield: 78\%. Elemental analysis (\%) calcd for (1) $\left(\mathrm{C}_{31.5} \mathrm{H}_{24} \mathrm{AuCuF}_{10} \mathrm{~N}_{4}\right): \mathrm{C} 41.62, \mathrm{H} 2.66, \mathrm{~N}$ 6.16; found: $\mathrm{C}$ 41.36, H 2.91, N 6.16; ${ }^{19} \mathrm{~F}\left(298 \mathrm{~K}, \mathrm{CD}_{3} \mathrm{CN}\right) \delta=-162.86(\mathrm{~m}$, $\left.2 \mathrm{~F}, \mathrm{~F}_{m}\right),-161.67\left(\mathrm{t}, 1 \mathrm{~F}, \mathrm{~F}_{p}, \mathrm{~J}_{F o-F p}=19.4 \mathrm{~Hz}\right),-114.86(\mathrm{~m}, 2 \mathrm{~F}$, $\left.\mathrm{F}_{\mathrm{o}}\right) \mathrm{ppm} ;{ }^{1} \mathrm{H}\left(298 \mathrm{~K}, \mathrm{CD}_{3} \mathrm{CN}\right) \delta=7.20\left(\mathrm{~m}, 5 \mathrm{H}, C_{6} H_{5}\right), 7.20$ $\left(\mathrm{m}, 3 \mathrm{H}, \mathrm{C}_{6} \mathrm{H}_{5}-\mathrm{CH}_{3}\right), 2.81\left(\mathrm{~m}, 4 \mathrm{H}\right.$, cis-NC- $\mathrm{CH}-\left(\mathrm{CH}_{2}\right)_{4}-\mathrm{CH}-$ $\mathrm{CN}), 1.84$ (m, 16H, cis-NC-CH- $\left.\left(\mathrm{CH}_{2}\right)_{4}-\mathrm{CH}-\mathrm{CN}\right), 2.74(\mathrm{~m}$, $4 \mathrm{H}$, trans-NC- $\left.\mathrm{CH}-\left(\mathrm{CH}_{2}\right)_{4}-\mathrm{CH}-\mathrm{CN}\right), 2.01(\mathrm{~m}, 8 \mathrm{H}$, trans-NC$\left.\mathrm{CH}-\left(\mathrm{CH}_{2}\right)_{4}-\mathrm{CH}-\mathrm{CN}\right), \quad 1.65\left(\mathrm{~m}, 8 \mathrm{H}\right.$, trans-NC-CH- $\left(\mathrm{CH}_{2}\right)_{4^{-}}$ $\mathrm{CH}-\mathrm{CN}) \mathrm{ppm}$.

Preparation of $\left[\mathrm{Cu}(\mathrm{N} \equiv \mathrm{C}-\mathrm{Cy}-\mathrm{C} \equiv \mathrm{N})_{2}\right]\left[\mathrm{Au}\left(\mathrm{C}_{6} \mathrm{~F}_{5}\right)_{2}\right] \cdot \mathrm{CH}_{2} \mathrm{Cl}_{2}$ (2) and $\left[\mathrm{AuCu}\left(\mathrm{C}_{6} \mathrm{~F}_{5}\right)_{2}(\mathrm{~N} \equiv \mathrm{C}-\mathrm{Cy}-\mathrm{C} \equiv \mathrm{N})_{2}\right] \cdot \mathrm{CH}_{2} \mathrm{Cl}_{2}(3)$

Slow diffusion n-hexane into a dichloromethane solution $(5 \mathrm{ml})$ of complex $\left[\mathrm{AuCu}\left(\mathrm{C}_{6} \mathrm{~F}_{5}\right)_{2}(\mathrm{~N} \equiv \mathrm{C}-\mathrm{Me})_{2}\right] \cdot 0.5$ Toluene (1) (150 mg, $0.221 \mathrm{mmol}$ ) led to complex 2 as colorless crystals suitable for X-ray diffraction studies.

Addition of dichloromethane $(20 \mathrm{ml})$ was added complex $\left[\mathrm{AuCu}\left(\mathrm{C}_{6} \mathrm{~F}_{5}\right)_{2}(\mathrm{~N} \equiv \mathrm{C}-\mathrm{Me})_{2}\right] \cdot 0.5$ Toluene (1) (150 mg, 0.221 $\mathrm{mmol})$. After few minutes of stirring evaporation of the solvent under vacuum led to complex $\mathbf{3}$ as a white solid. Yield: $40 \%$.

Elemental analysis (\%) calcd for (2 and 3) $\left(\mathrm{C}_{29} \mathrm{H}_{30} \mathrm{AuCl}_{2} \mathrm{CuF}_{10} \mathrm{~N}_{4}\right): \mathrm{C} 36.74, \mathrm{H}$ 2.34, N 5.91; found: $\mathrm{C}$ $36.63, \mathrm{H} 2.50, \mathrm{~N} \mathrm{5.73;}{ }^{19} \mathrm{~F}\left(298 \mathrm{~K}, \mathrm{CD}_{3} \mathrm{CN}\right) \delta=-162.86(\mathrm{~m}$, $\left.2 \mathrm{~F}, \mathrm{~F}_{m}\right),-161.64\left(\mathrm{t}, 1 \mathrm{~F}, \mathrm{~F}_{p}, \mathrm{~J}_{F o-F p}=19.5 \mathrm{~Hz} \mathrm{~Hz}\right),-114.86(\mathrm{~m}$, $\left.2 \mathrm{~F}, \mathrm{~F}_{\mathrm{o}}\right) \mathrm{ppm} ;{ }^{1} \mathrm{H}\left(298 \mathrm{~K}, \mathrm{CD}_{3} \mathrm{CN}\right) \delta=5.45\left(\mathrm{~m}, 2 \mathrm{H}, \mathrm{CH}_{2} \mathrm{Cl}_{2}\right)$, $2.81\left(\mathrm{~m}, 4 \mathrm{H}\right.$, cis- $\left.\mathrm{NC}-\mathrm{CH}-\left(\mathrm{CH}_{2}\right)_{4}-\mathrm{CH}-\mathrm{CN}\right), 1.84$ (m, $16 \mathrm{H}$, cis$\left.\mathrm{NC}-\mathrm{CH}-\left(\mathrm{CH}_{2}\right)_{4}-\mathrm{CH}-\mathrm{CN}\right), \quad 2.74 \quad(\mathrm{~m}, \quad 4 \mathrm{H}, \quad$ trans-NC- $\mathrm{CH}-$ $\left.\left(\mathrm{CH}_{2}\right)_{4}-\mathrm{CH}-\mathrm{CN}\right), 2.01$ (m, 8H, trans-NC-CH- $\left(\mathrm{CH}_{2}\right)_{4}-\mathrm{CH}-$ $\mathrm{CN}), 1.66\left(\mathrm{~m}, 8 \mathrm{H}\right.$, trans-NC-CH- $\left.\left(\mathrm{CH}_{2}\right)_{4}-\mathrm{CH}-\mathrm{CN}\right) \mathrm{ppm}$.

\section{Crystallography}

The crystal was mounted in inert oil on glass fibbers and transferred to the cold gas stream of a Nonius Kappa CCD diffractometer equipped with an Oxford Instruments lowtemperature attachment. Data were collected by monochromated Mo K $\alpha$ radiation $(\lambda=0.71073 \AA$ ). Scan type $\omega$ and $\phi$. 
Absorption corrections: numerical (based on multiple scans). The structure was solved by direct methods and refined on $F^{2}$ using the program SHELXL-97 [19]. All non-hydrogen atoms were anisotropically refined and hydrogen atoms were included using a riding model. Crystal data: $\mathrm{C}_{28} \mathrm{H}_{20} \mathrm{AuCuF}{ }_{10} \mathrm{~N}_{4} \cdot \mathrm{CH}_{2} \mathrm{Cl}_{2}$, monoclinic, $\mathrm{C} 2 / \mathrm{c}, a=31.9080(4)$, $b=9.7803(2), \quad c=25.3001(4) \quad \AA, \quad \beta=122.0585(11)^{\circ}$, $V=6691.36(19) \AA^{3}, Z=8, \mu=5.258 \mathrm{~mm}^{-1}, 49944$ reflections $2 \theta_{\max } 56^{\circ}, 7982$ unique $\left(R_{\mathrm{int}}=0.1013\right), R=0.0456, R_{\mathrm{w}}=0.1048$ for 424 parameters, 138 restrictions, $S=1.027$, max. $\Delta \rho=2.718 \mathrm{e}^{-3}$. Selected bond lengths and angles are shown in Table $\mathrm{x}$ and crystal structure of $\mathbf{2} \cdot \mathrm{CH}_{2} \mathrm{Cl}_{2}$ can be seen in Figs. (1 and 2). CCDC-682006 contains the supplementary crystallographic data for this paper. These data can be obtained free of charge via www.ccdc.cam.ac.uk/conts/retrieving.html (or from the Cambridge Crystallographic Data Centre, 12 Union Road, Cambridge CB2 1EZ, UK; fax: (+44) 1223-336-033; or email: deposit@ccdc.cam.ac.uk).

\section{REFERENCES}

[1] Pyykkö, P. Angew. Chem. Int. Ed., 2004, 43, 4412.

[2] Pyykkö, P. Inorg. Chim. Acta, 2005, 358, 4113.

[3] Fernández, E. J.; Laguna, A.; López-de-Luzuriaga, J. M. Dalton Trans., 2007, 1969.
[4] Fernández, E. J.; Laguna, A.; López-de-Luzuriaga, J. M.; Monge, M.; Montiel, M.; Olmos, M. E.; Rodríguez-Castillo, M. Organometallics, 2006, 25, 3639

[5] Fernández, E. J.; Laguna, A.; López-de-Luzuriaga, J. M.; Monge, M.; Montiel, M.; Olmos, M. E. Inorg. Chem., 2007, 46, 2953.

[6] Fernández, E. J.; Laguna, A.; López-de-Luzuriaga, J. M.; Olmos, M. E.; Pérez, J. Dalton Trans, 2004, 1801

[7] Fernández, E. J.; Laguna, A.; López-de-Luzuriaga, J. M.; Monge, M.; Montiel, M.; Olmos, M. E. Inorg. Chem., 2005, 44, 1163.

[8] Knaust, J. M.; Lopez, S.; Keller, S. W. Inorg. Chim. Acta, 2001, 324,81 .

[9] Forward, J. M.; Fackler, J. P., Jr.; Assefa, Z. in Optoelectronic Properties of Inorganic Compounds Roundhill, D.M.; Fackler, J.P. Jr., Ed.; Plenum, New York, 1999, pp. 195-226.

[10] Che, C.-M.; Mao, Z.; Miskowski, V. M.; Tse, M.-C.; Chan, C.-K.; Cheung, K.-K.; Phillips, D. L.; Leung, K.-H. Angew. Chem. Int Ed., 2000, 39, 4084.

[11] Ford, P. C.; Cariati, E.; Bourassa, J. Chem. Rev., 1999, 99, 3625.

[12] Simon, J. A.; Palke, W. E.; Ford, P. C. Inorg. Chem., 1996, 35 , 6413.

[13] McMillin, D. R.; McNett, K. M. Chem. Rev., 1998, 98, 1201.

[14] Sakaki, S.; Mizutani, H.; Kase, Y. Inorg. Chem., 1992, 31, 4575.

[15] Eggleston, M. K.; McMillin, D. R.; Koenig, K. S.; Pallenberg, J. A. Inorg. Chem., 1997, 36, 172.

[16] Everly, R. M.; Ziesel, R.; Suffert, J.; McMillin, D. R. Inorg. Chem., 1991, 30, 559.

[17] Shinozaki, K.; Kaizu, Y. Bull. Chem. Soc. Jpn., 1994, 67, 2435.

[18] See Suplementary Material

[19] Sheldrick, G. M. SHELXL-97, Program for Crystal Structure Refinement, University of Göttingen, Germany, 1997. 


\section{SUPPLEMENTARY MATERIAL}

\section{Experimental Section}

Solvents used in the spectroscopic measurements were dried and distilled under an argon atmosphere. $\left[\mathrm{Au}_{2} \mathrm{Ag}_{2}\left(\mathrm{C}_{6} \mathrm{~F}_{5}\right)_{4}(\mathrm{~N} \equiv \mathrm{C}-\mathrm{Me})_{2}\right]_{\mathrm{n}}{ }^{[1]}$ was prepared according to literature methods. $\mathrm{CuCl}$ (Aldrich) was used as received

Preparation of $\left[\mathrm{AuCu}\left(\mathrm{C}_{6} \mathrm{~F}_{5}\right)_{2}(\mathrm{~N} \equiv \mathrm{C}-\mathrm{Me})_{2}\right]$

To an acetonitrile solution $(20 \mathrm{ml})$ of $\left[\mathrm{Au}_{2} \mathrm{Ag}_{2}\left(\mathrm{C}_{6} \mathrm{~F}_{5}\right)_{4}(\mathrm{~N} \equiv \mathrm{C}-\mathrm{Me})_{2}\right]_{\mathrm{n}}(96 \mathrm{mg}, 0.070 \mathrm{mmol})$ was added $\mathrm{CuCl}(14 \mathrm{mg}, 0.141$ $\mathrm{mmol}$ ) and a precipitate is observed $(\mathrm{AgCl})$. The mixture was stirred for 2 hours and the solid was eliminated by filtration. The solvent was evaporated to $c a .5 \mathrm{ml}$. Addition of diethylether $(20 \mathrm{ml})$ led to precipitation of complex $\mathbf{1}$ as a white solid. Yield: $70 \%$. Elemental analysis (\%) calcd for $\left(\mathrm{C}_{16} \mathrm{H}_{6} \mathrm{AuCuF}_{10} \mathrm{~N}_{2}\right): \mathrm{C} 28.40, \mathrm{H} \mathrm{0.89,} \mathrm{N} \mathrm{4.14;} \mathrm{found:} \mathrm{C} 28.30, \mathrm{H} 0.77, \mathrm{~N} 5.13 ;{ }^{19} \mathrm{~F}\left\{{ }^{1} \mathrm{H}\right\}$ $\left(298 \mathrm{~K}, \mathrm{CD}_{3} \mathrm{CN}\right) \delta=-162.84\left(\mathrm{~m}, 2 \mathrm{~F}, \mathrm{~F}_{m}\right),-161.64\left(\mathrm{t}, 1 \mathrm{~F}, \mathrm{~F}_{p}, \mathrm{~J}_{F o-F p}=19.4 \mathrm{~Hz}\right),-114.80\left(\mathrm{~m}, 2 \mathrm{~F}, \mathrm{~F}_{\mathrm{o}}\right) \mathrm{ppm} ;{ }^{1} \mathrm{H}\left(298 \mathrm{~K}, \mathrm{CD}_{3} \mathrm{CN}\right)$ $\delta=1.95\left(\mathrm{~s}, 3 \mathrm{H}, \mathrm{CH}_{3}\right) \mathrm{ppm}$; MS: $m / z(\%) 531.3\left[\mathrm{Au}\left(\mathrm{C}_{6} \mathrm{~F}_{5}\right)_{2}\right]^{-}, 1125.4\left[\mathrm{Au}_{2} \mathrm{Cu}\left(\mathrm{C}_{6} \mathrm{~F}_{5}\right)_{4}\right]^{-}(\mathrm{ES}-)$. 